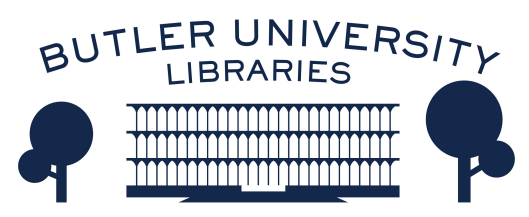

Journal of Hindu-Christian Studies

Volume 7

Article 11

January 1994

\title{
Viewpoint: Religious Fundamentalism and Pluralism in India
}

David C. Scott

Follow this and additional works at: https://digitalcommons.butler.edu/jhcs

Part of the Religion Commons

\section{Recommended Citation}

Scott, David C. (1994) "Viewpoint: Religious Fundamentalism and Pluralism in India," Journal of HinduChristian Studies: Vol. 7, Article 11.

Available at: https://doi.org/10.7825/2164-6279.1099

The Journal of Hindu-Christian Studies is a publication of the Society for Hindu-Christian Studies. The digital version is made available by Digital Commons @ Butler University. For questions about the Journal or the Society, please contact cbauman@butler.edu. For more information about Digital Commons @ Butler University, please contact digitalscholarship@butler.edu. 


\title{
VIEWPOINT
}

\section{Religious Fundamentalism and Pluralism in India}

\author{
David C. Scott \\ United Theological College \\ Bangalore, India
}

MUCH HAS BEEN written and said in recent months about religious fundamentalism and pluralism in India. However, in order to understand what is currently going on in India with regard to these two phenomena, a third really needs to be brought into the picture - communalism. Indeed, one could well argue, though I have neither the time nor the space here, that the fundamentalisms of India - whether Muslim, Sikh, Hindu, Buddhist, or Christian - were conceived in communally perceived times of crisis. Basically fundamentalist movements in India are critiques of contemporary ways of life and look to a future; determined by the past, where the "true believer" is twice blessed with true faith and secular power. They are defensive movements which resort to a selective retrieval of the tradition and, in the process, its redefinition. In very selfserving ways they do not ignore the resources available to them in the present, including modern knowledge and technology, but they do reject the ideologies of modernism and secularism. They envelop themselves in an aura of idealism, but are generally aggressive, if not violent in character. They are totalitarian and intolerant of dissent. Each fundamentalism has a positive self-image and generates a self-justifying rhetoric - verbally, in writing and on videotape. Fundamentalism in India has an essentially communal character. But what does communalism mean in India today?

Today the initiative in defining communalism in India has been seized by fundamentalists in the majority community, which is projecting communalism as true nationalism; the nation belongs to the majority and is formed by their history, culture and struggles. Nationalism and communalism are made synonymous, and Indian nationalism is imputed a Hindu religious character. Indeed, constructing a religious-national identity is the current state of play of majority communal fundamentalism. Integral to the creation of this identity is a clearly discernible shift of emphasis from communal to religious politics. And so fundamentalism re-enters the picture, as the focus is now on the religious consciousness in society and its mobilization for political ends.

The mobilizing potential of communalism lies in its linkages with the religious beliefs of people. The aggressive propaganda through the invocation of religious symbols has implanted religious fundamentalism in popular consciousness. This may be seen, for example, in the program to construct a Ram temple as the common cause of Hindus, regardless of sectarian differences within the Hindu tradition. In several parts of the country, particularly in the south and east, Ram is not a particularly popular deity. 
But even in these areas, the temple campaign has succeeded in making the veneration of Ram central to contemporary Hindu fundamentalism.

Organizing politics around such a common religious aspiration has a greater potential for success than resorting to communal hatred and antagonism. A true believer is unlikely to subscribe to the politics of communal hatred or approve of killings in the name of religion. Yet he or she may support political programs which advocate the fulfilment of common religious interests. Communalism, therefore, increasingly identifies itself with aggressive religious faith and operates its politics in the guise of religious interests.

A practical implication of this is a shift of focus from "they" to "us". The tactical change is due to the fact that religion and politics need no mixing in India; they mix themselves, given the grip religion has on contemporary social consciousness. The religious world of most Hindus, for example, is more or less confined to a few simple practices, such as reciting some lines of scripture or applying sandal paste or pausing devoutly before an image of deity. They entertain no hatred towards followers of other religious traditions nor target for attack others' places of worship in order to correct historical wrongs. Yet they have an unmistakable identity and attachment to their own religious tradition. They are religious. When communities are constructed and mobilized, religious loyalties no longer remain private; they easily coalesce with the beliefs of others in the community and enter the public sphere. It thus becomes natural, for instance, for a housewife who daily reads the Ramayana as a religious rite to identify herself with the construction of a Ram temple and to become a votary of the politics which seek support from religious faith.

Perhaps it is true of all fundamentalism, but the current fundamentalist discourse in India draws heavily on the past, through what M.M. Bakhtin calls "historical inversion". Thus values like purpose, ideal, justice, perfection, social harmony are located in the past. Myths about paradise, a Golden Age, an heroic age, ancient truth and so forth are all expressions of this historical inversion. Simplified, this means that something that could and in fact must be realized in the present and future is portrayed as a thing out of the past. This imparts to fundamentalism of all sorts a definite retrogressive character, which is not to be confused with a critical and creative introspection of the past. Instead the past is valorized in a manner that stultifies the present and endangers the future, not only for pluralism.

The notion of "ancient truth" as an ideal for the future has far-reaching implications, the most important of which is that the future is given and not subject to choice. This injects an authoritarian and dogmatic element into the programs of fundamentalist religion which is destructive of pluralism. Dialogue appears to be alien to fundamentalism. The controversy last year over Sahmat's pluralist exhibition, in which one display depicted a variant tradition in which Ram and Sita were brother and sister, is a case in point. The vehement, sometimes even violent, reaction to this was based on the assertion of the "ancient truth" that Ram and Sita were, in fact, husband and wife. No other possibility could be entertained.

Coercion is another component of contemporary Indian religious fundamentalism. Its proceedings tend to put considerable pressure on the individual's free choice. This was most acutely felt by religious Hindus who, even if they did not approve of the politics of rath yatra and Ram sila puja, felt compelled to support the construction of the temple. How could a devout Hindu disapprove of efforts to build a temple for Ram without compromising his/her faith? Once religious identity was invoked, there was no choice but to support the venture. Even those Hindus who were not devotees of Ram found their Hindu identity in peril unless they lent their voice to favour the 
mandir.

Exposed to the influences of almost all the world's religions, Indian intellectual tradition has, in fact, been enriched by theological debate and discussion. These interactions were not confined to religious disputations alone. They often embraced the entire gamut of social existence and thus assumed far greater philosophical relevance. From early times to the late 19th century, all religious traditions were participants in these debates. The discussions inevitably underlined differences, but they also explored areas of agreement. The interpenetration of ideas occurring as a consequence marked a very creative phase in the religious history of India. This important legacy of religious thought appears totally lost on contemporary religious fundamentalism. Is it because a principle of pluralism fostering religious solidarity and harmony is not conducive to the interests of communal fundamentalism which underlines division rather than unity in the pursuit of power? Muslim fundamentalism is not informed by Akbar's "Din-i-Ilahi" or Sayed Ahmad Khan's understanding of the Qur'an and Hadith. So also, Hindu fundamentalism is insensitive to the universal spirit of Hindu philosophers, bhaktas and reformers. Instead the fundamentalists are constantly in search of what is uniquely "Hindu" or "Muslim" in their past.

To the extent that fundamentalist ideology is derived from assumptions of history, politics and culture, which are not open to scrutiny and discussion, a genuine pluralism seems unlikely at present. As the members of Sahmat painfully discovered, there seems to be no genuine meeting ground. Regrettably, negotiation is mistaken for dialogue, with secularists feigning to be either honest brokers or neutral observers. What is required urgently is a shift from the culture of negotiation to a climate of dialogue. For that an atmosphere of openness, devoid of coercion and intellectual dishonesty, is necessary. Such a change is imperative if the existing religious consciousness in India is to be prevented from being overwhelmed by communal fundamentalism. Any compromise dictated by political expediency does not offer a solution. This would eventually bring the camel right into the tent. 